\title{
The Development of Student Worksheet Based on Pictorial Riddle Model to Improve Critical Thinking Ability in Elementary School
}

\author{
Eka Septiana $^{1^{*}} \quad$ Nurlaksana Eko Rusminto $^{2} \quad$ Caswita $^{3} \quad$ Alben Ambarita $^{4}$ \\ Faculty of Teacher Training and Education, University of Lampung \\ St. Soemantri Brojonegoro No.1 Gedung meneng Bandar Lampung 35145
}

\begin{abstract}
This research and development aims to develop and describe the feasibility and effectiveness of mathematics student worksheet based on pictorial riddle model in improving students' critical thinking skills. The type of research used is research and development that refers to the theory of Borg and Gall. The population of this study was fourth grade students of Elementary Schools in Bangunrejo. The study sample was 32 fourth grade students of Tanjung Jaya Public Elementary School 1 which were determined by purposive sampling technique. Data was collected through questionnaire sheets, observation sheets and test questions. The results of the study showed that the student worksheet based on pictorial riddle model was feasible, and effective for improving students' critical thinking skills.
\end{abstract}

Keywords: The development of student worksheets, pictorial riddle.

DOI: $10.7176 / \mathrm{JEP} / 10-23-01$

Publication date: August $31^{\text {st }} 2019$

\section{INTRODUCTION}

Education has a very important role in improving the quality of human resources. The level of quality of human resources possessed by a nation will influence the level of progress of a nation. Therefore, the quality of education must continue to be improved and harmonized with the demands of the times. The ability that must be possessed by students in education in the 21 st century are Creativy, Critical Thinking, Communication, and Collaboration (4C) Bialik (2015: 1). One of the abilities needed in the 21st century is critical thinking. According to Alazzi (in Mesfer 2014: 38) it takes citizens who are educated and have a qualified workforce and the ability of citizens to think critically and rationally is considered an important result of education. Critical thinking helps an individual to solve the problem. Ennis (in Fisher 2009: 5) argues that critical thinking is a process that aims to make sound decisions, so what is thought in mind is the best of the truth that can be done correctly.

Amri and Ahmadi (2015: 149-152) stated that critical thinking is a cognitive activity that related to the use of reason. Reasoning is part of critical thinking activities. Next is De Porter. et al (2013: 298) stated that critical thinking is a high-level skill that is very important to students in addition to creative thinking skills. According to Kowiyah (2012:175) critical thinking is a mode of thinking about a matter, substance or any problem, in order to improve the quality of his thinking by handling skillfully the structures inherent in thinking and applying intellectual standards to him. Students' critical thinking skills do not arise automatically in students. But, it needs to be a learning approach, both methods or learning resources used to improve students' critical thinking skills. The curriculum that used in the current learning process is Curriculum2013. Curriculum 2013 is a competencybased curriculum which formulates integrated attitudes, knowledge, and skills that must be mastered by students. Related to mathematics learning in the Curriculum 2013 the implementation of learning in Elementary / Madrasah Ibtidaiyah using thematic-integrated learning approach, except for Mathematics and Physical Education Sport and Health subjects in the low class mathematics integrated in a theme, while for high-class mathematics stand alone as subjects. Curriculum 2013 in the implementation of the teacher must act as a facilitator and students must be more active so as to stimulate students to think critically.

The consideration of choosing Student Worksheet in this study is because Student Worksheet that used in schools is Student Worksheet especially mathematics that is bought from the market which only contains tasks in the form of counts that must be completed by students and more about cognitive knowledge, lacking in the field of affective and psychomotor, even though Student Worksheet that good is not only contains a collection of questions that students must complete, but it is necessary to have steps that guide students in finding the concept of knowledge that they will get. Student Worksheet is also certainly not in accordance with the Curriculum 2013 which emphasizes the development of a balance between spiritual, social, knowledge and skills, and applying it in various situations in schools and communities, then Student Worksheet needs to be packaged and presented in the form of work instructions structured and systematic that is able to invite and guide students in activities in the learning process so that students are able to understand and study the material independently and facilitate students' critical thinking skills.

The results of the Trends in International Mathematics and Science Study (TIMSS) study in 2015 showed that the achievement position of fourth grade students showed that in Indonesia scores with an average of 397 ranked 44th out of 56 countries. The TIMSS assessment information shows that the performance of Indonesian 
students is still low. This category requires students to master the concept well, can organize information, make announcements, solve non-routine problems, take and submit conclusions justification arguments. The domain of the average Indonesian score survey conducted by TIMMS is knowing (knowledge), applying (applying), and reasoning (reasoning). According to the 2015 International for Student Assessment (PISA) Program survey, Indonesia ranked 68 out of 76 countries. The fact that happened in Indonesia is that students' current critical thinking skills are still low. The survey conducted by the OECD in 2016 showed that the majority of Indonesian students have not been able to develop critical thinking skills. From year to year, Indonesia experienced an increase in the average score, but Indonesia was still in the lower rank. In 2009 Indonesia was ranked 5th from below, in 2012 the average score of Indonesia rose but its ranking dropped to 2 from below and in 2015 Indonesia increased the average score and ranked 9th from the bottom. Based on the survey shows that students' critical thinking skills in Indonesia have increased despite being below the average in the international community

The riddle pictorial learning model described by Sulistiyani $(2015: 23)$ is one part of the inquiry model because the learning process emphasizes the question and answer activities and finds a concept for itself. According to Sund in Masfuah (2016: 106) Pictorial riddle is one model of inquiry that can develop motivation and interest in the form of images, demonstrations, or real situations that can be used to improve students' critical and creative thinking. Student Worksheet is very well used in the context of heuristic and expository strategies. Heuristic Strategy of Student Worksheet are used in guided discovery models, while in expository strategies Student Worksheet are used to provide developmental training. This was stated by Lee (2014: 96) Student Worksheet can be useful in terms of academic achievement. For example, as a support for textbooks. Student Worksheet can be used to add information to a particular class. In addition, Student Worksheet can be used by students to construct knowledge. Related to the results of observations of researchers about teaching materials that used Student Worksheetwhich used by students are not made directly by the teacher so that it is not in accordance with the needs of students. The Student Worksheet that is used is from the publisher but it has not led students to experience firsthand, so that students cannot develop their critical thinking skills. Learning is carried out by educators oriented only to the extent of completing the material that contained in the book alone and less linking with the experience that experienced by direct students. So that students' critical thinking skills are not optimally developed even though schools have used the curriculum 2013.

Based on the needs analysis that obtained from questionnaires, it shows that $100 \%$ of educators have never applied learning based on Riddle reciprocal pictorial model. Based on this background the researcher intends to use the riddle pictorial model in improving the learning process in order to obtain the desired results so as to improve critical thinking skills in the material explaining the breadth and circumference of square, rectangular and triangular through pictorial riddle model on fourth gradeof Elementary School in Bangunrejo.

\section{METHODS}

This study uses research and development referring to the theory of Borg \& Gall (1983: 772) on Reasearch \& Development according to the research objectives, namely research procedures with the aim of developing and validating educational products developed. Borg and Gall (2003: 569-575) research and development procedures, namely research and information collecting, planning, developing preliminary form of product, preliminary field testing, main product revision, playing field testing, operational product revision, operational field testing, final product revision, and dissemination and implementation. The research and development carried out only reached the seventh step, because of the limitations of researchers, both in terms of time and cost. The study population was fourth grade students at the Bangunrejo District Elementary School who had implemented the 2013 curriculum. The sample was determined using purposive sampling with the consideration that Tanjung Jaya Public Elementary School 1 was the 2013 curriculum model implementation school and had a number of students who fit the criteria, in this case the sample 32 students were used.

Data collection tool for developing Student Worksheet based on the pictorial riddle model is used a questionnaire, that are material and media validation. Material aspects of Student Worksheet include conformity with the model and curriculum2013, and quality of content. Media aspects of Student Worksheet fulfill didactic, construction, and technical requirements. Learning outcomes obtained from the results of the pretest and posttest of learning using Student Worksheet oriented to the pictorial riddle model, using valid and reliable test instruments, and considering the level of difficulty and the power of the different questions. Instrument form essays by giving a score that varies according to the level of difficulty of the question. The results of learning critical thinking skills using an observation sheet. Product effectiveness test is done to see the students' critical thinking skills seen from the learning outcomes of students before and after learning using Student work sheet based on predictorial riddle. $\mathrm{N}$-Gain was used to analyze the increase in the results of critical thinking learning before and after learning by using a work sheet based on pictorial riddle. 


\section{RESEARCH RESULTS AND DISCUSSION \\ 3.1 Research Result}

The results of the research and development of student worksheet based on pictorial riddle mathematics students of fourth grade students of Tanjung Jaya Public Elementary School 1, product development with the development procedure referring to the development model of Borg \& Gall (2003: 569-575) obtained the following results.

\subsubsection{Collection of Initial Information}

The initial information collection was carried out through preliminary research by identifying the learning process and collecting learning outcomes in the fourth grade of Elementary Schools in Bangunrejo. The results of the preliminary research are used as a consideration and basis for the development of student worksheet. This step needs to be done because this development research tests a teaching material in the form of mathematical based student worksheet on Pictorial Riddle whose development must be based on empirical data about the profile and subject under study. Based on the results of the observation of the analysis of student learning outcomes and the needs analysis of educators in November 2018 in the fourth grade of Public Elementary Schools in Bangunrejo District.

\subsubsection{Planning}

Planning of the development of the Mathematics Student Worksheet based on the pctorial riddle is, the preparation of a Student Worksheet based on pictorial riddle framework, presentation of material adapted to steps, planning evaluation tools, and preparation of assessment instruments.

\subsubsection{Development of Student Worksheets}

Steps for developing Student Worksheet are 1) Assessment of material in Student Worksheets, 2) Drafting of Student Worksheet based on pictorial riddle. Development of the initial product format of Student Worksheet that has been compiled and consists of a) cover page includes: (i) the title is determined based on the design stage, (ii) the name of the Student Worksheet Eka Septiana, (iii) Identity of Student Worksheet for administrative needs, (iv) supporting images to briefly describe the contents of the Student Worksheet that are developed to briefly describe the contents of the developed Student Worksheets, (v) the user objectives of the Student Worksheet developed, b) preface , c) table of contents, d) mapping of basic competencies, e) learning objectives, f) preparation of contents of Student Worksheets.

\subsubsection{Product Trials}

Initial product testing was carried out by material experts, media experts, and validation of fourth grade educators. The results of material validation by material experts obtained a value of 78.20 in the first validation and 96.73 in the second validation. The results of media validation by media experts obtained the first validation value of 87.00 and the second validation was 93.00. The validation test of fourth grade educators has a value of 91.48 . Suggestions and input from validation experts are indicators developed in accordance with Basic Competencies, completing Student Worksheet with steps of the Riddle pictorial model, replacing images on Student Worksheet with varied and applied images, pictorial riddles made with reference to critical thinking, replacing foreign words or difficult words to be easily understood by students, replacing images displayed with photos around the school, replacing images displayed with photos around the school, improving learning objectives. After the product was revised, a small group trial was conducted in the fourth grade A class of Elementary School 1 in Tanjung Jaya. Small group assessments are carried out by 10 students consisting of low, medium and high-ability students.

3.1.5 Revision of Initial Products

Based on the results of the trial of the Math Student Worksheet based on pictorialriddle in small groups obtained that the results of the increase in critical thinking skills and learning outcomes of students. So this Student Worksheet is not revised, and is feasible to be tested in large groups.

\subsubsection{Main Field Trials}

The subjects of the large group trial were the fourth grade B class students of Elementary School 1 in Tanjung Jaya totaling 32 students. Before the learning activities, in the first meeting students do the pretest and posttest at the third meeting. This is intended to see the effectiveness of the Mathematics Student Worksheet based on Riddle pictorial whether there is an increase in learning outcomes before and after learning is done using the Mathematics Student Worksheet based on Riddle pictorial. The results of observations of critical thinking skills from 32 large group students there were 3 students $(9.37 \%)$ in very good category, 16 students $(50 \%)$ in good category, 13 students $(40.62 \%)$ with quite good categories, and there are no students with less categories. The data shows that students' critical thinking skills both during the learning process use the Mathematics Student Worksheet based on Riddle pictorial.

\subsubsection{Revised Final Products}

Based on large group trials, the results of increased critical thinking skills and student learning outcomes were obtained. Student learning outcomes, material expert validation, media experts and practitioners become references in making conclusions that Mathematics Student Worksheet based on Riddle pictorial is not revised and is feasible to implement. 


\subsubsection{Test the effectiveness of Student Worksheets}

Product effectiveness test is done to see the existence of students' critical thinking abilities seen from the learning outcomes of students before and after learning using the Mathematics Student Worksheet based on Riddle pictorial. The average learning outcome of the fourth grade students' pretest was 59.81 and the posttest results of students increased to 79.74 and the average N-Gain results showed 0.50 which means that the normalized gain is in the "moderate" classification, then effective level. Thus it can be seen that the Mathematics Student Worksheet based on Riddle pictorial is effective in fostering students' critical thinking skills.

\subsection{Discussion}

\subsubsection{Development of Student Worksheet}

Development of Mathematics Student Worksheet based on Riddle pictorial focused on the fourth grade in Basic Competence. Development of Mathematics Student Worksheet based on Riddle pictorial teaching adapted from the R \& D step by Borg \& Gall (1983: 784) by using seven out of ten steps. The first stage was the initial research and information gathering, after the researcher found out the problem the researcher made a plan to develop Mathematics Student Worksheet based on Riddle pictorial tat will be used by students so that they can improve critical thinking skills seen from the learning outcomes of students. Next the researcher compiled the development of the initial product of the Student Worksheet, in this step the researcher poured the pattern of developing the content and design of Mathematics Student Worksheet based on Riddle pictorial in accordance with the pictorial riddle steps. The next stage is the initial trial. This stage the researcher conducted a validation test and a small group trial. The validation test was carried out by three validators, that are matrians, media experts, and fourth grade educators with the aim of validating the products developed whether they were in accordance with the development requirements so that they were feasible to be tested. The results of material validation by material experts obtained a value of 78.20 in the first validation and 96.73 in the second validation. The results of media validation by media experts obtained the first validation value of 87.00 and the second validation was 93.00. The validation test of fourth grade elementary school educators obtained a score of 91.48. Researchers conducted product revisions on suggestions and comments from the validators. After the product is declared valid and feasible to be tested, then the next stage is a small group trial involving ten students. The results obtained based on the pretest and posttest have an increase in the results of students' critical thinking learning. Then the researcher made a revision to improve the product. Next is the field trial stage, the product of the Mathematics Student Worksheet based on Riddle pictorial in the learning process. This field trial phase was used to determine the effectiveness of Mathematics Student Worksheet based on Riddle pictorial in improving critical thinking skills seen from the learning outcomes of students at the pretest and posttest. Based on the results of the effectiveness test that has been done, the data obtained is an increase in student learning outcomes before and after using Mathematics Student Worksheet based on Riddle pictorial. Therefore, the product of this Mathematics Student Worksheet based on Riddle pictorial is not revised and is feasible to implement.

3.2.2 The Effectiveness of Mathematics Student Worksheet based on Riddle pictorial

The effectiveness test is done to find out the effectiveness of Mathematics Student Worksheet based on Riddle pictorial in the learning process that has been done and the learning outcomes of students which refers to the ability to think critically. The effectiveness test is used to see critical thinking skills, and student learning outcomes. The effectiveness test was carried out on 32 fourth grade students of Public Elementary School 1Tanjung Jaya.The Mathematics Student Worksheet that was tested included material explaining the circumference and area of a square, rectangle and triangle. The results of observations of critical thinking skills in small groups were 10 students in a small group of 2 students (20\%) with very good categories, 5 students $(50 \%)$ with good categories, 3 students $(30 \%)$ with fairly good categories, and no students with less categories. In the large group there were 3 students $(9.37 \%)$ in the very good category, 16 students $(50 \%)$ in the good category, 13 students $(40.62 \%)$ with quite good categories, and no students with less categories. Based on the test results of learning can be seen that there is an increase in students' critical thinking skills in small groups and large groups after using Mathematics Student Worksheet based on Riddle pictorial. To find out the effectiveness of using the Mathematics Student Worksheet based on Riddle pictorial on critical thinking skills by looking at the learning outcomes of students before and after using Mathematics Student Worksheet based on Riddle pictorial.

Based on the effectiveness test using N-Gain obtained results of critical thinking learning of students after using Mathematics Student Worksheet based on Riddle pictorialis higher than before using previous Student Worksheet. The results of the recapitulation of the average N-Gain in the field trial obtained an average of 0.50 which means that the normalized gain is in the classification of "Medium", then the level of effectiveness is effective. In addition, the results of the analysis of critical thinking indicators indicate the existence of each indicator, that are identifying, analyzing, connecting, solving problems. Mathematics Student Worksheet based on Riddle pictorial are designed to facilitate students with interesting and fun learning. the ability to find solutions to problem solving. This is in accordance with the theory put forward by Faturraohman (2015: 205) that Pictorial Riddle is a learning model that can develop students' motivation and interest in small group discussions or large 
groups that can be used to improve critical and creative thinking through images. The learning process carried out with Pictorial Riddle Student Worksheet makes students more active so as to make student activities more active where children do so that they can improve students 'critical thinking skills because after conducting research it can be seen that participants' critical thinking skills do not appear with itself, it needs an effort to improve students 'critical thinking skills by actively involving students in the learning process in accordance with Musharafa's opinion (2016: 28) which explains that students' critical thinking skills can be improved by learning which involves more active students in the process learning. Although the quantity of material developed in Mathematics Student Worksheet based on Riddle pictorial only takes one basic competency, it still does not reduce the value that Mathematics Student Worksheet based on Riddle pictorial are one of the alternative innovations that are good teaching materials and can be used in learning to achieve goals learning. The Mathematics Student Worksheet based on Riddle pictorial is suitable to be used as a reference and companion for developing the subject matter found in student book that used curriculum 2013, because the Student Worksheet was developed in reference to the mathematics bookthat used curriculum 2013.

\section{CONCLUSION}

Based on the data analysis of research and development with the title "Development of Mathematical Student Worksheet based on pictorial riddle to Improve Critical Thinking Ability of Fourth Grade Elementary School Students" it can be concluded that the product of Mathematical Student Worksheet based on pictorial riddle is valid, both theoretically and empirical. Valid theoretically, that has fulfilled conformity with material and media aspects. This is evidenced by the results of material validation obtaining a value of 96.73 in the "Valid" category, the validation of media experts obtaining a score of 93.00 in the "Valid" category, and the validation of fourth grade B class teachers with a value of 91.48 in the "Valid" category. Valid empirically that is based on the results of a small group trial there is an increase in student learning outcomes before and after using the Mathematical Student Worksheet based on pictorial riddle with an average score at pretest of 59.81 increasing to 79.74 in the posttest. Furthermore, the Math Worksheet on the Mathematical Student Worksheet based on pictorial riddle is effectively used in the learning process for the fourth grade students of Public Elementary School 1 Tanjung Jaya to improve their critical thinking skills. This is proved by the learning outcomes of students in the pretest and posttest scores gaining a gain of 0.50 with the category "Medium".

\section{REFERENCES}

Amri \& Ahmadi. 2015. Implementasi Pembelajaran Aktif dalam Kurikulum 2013. Prestasi Pusakaraya, Jakarta.

Bailik, M \& Fadel, C. 2015. Skill for the $21^{\text {st }}$ Century. Center for Curriculum Redesign, Boston.

Borg, Walter R., dan Gall, Meredith Damien. 1983. Education Research. New York.

Burns, Marilyn. 2007. About Teaching Mathematic. Math Solution Publitions. USA.

DePorter, Bobbi. dkk. 2013. Quantum Learning: Membiasakan Belajar Nyaman dan Menyenangkan. Kaifa. Bandung.

Fathurrohman, M. 2015. Paradigma Pembelajaran Kurikulum 2013. Kalimedia, Yogyakarta.

Fisher, Alec. 2009. Berpikir Kritis Sebuah Pengantar. Erlangga. Jakarta.

OECD. 2016. PISA 2015 Results in Fokus : Excellence and Equity in Education. Volume I. https://www.oecd.org/pisa/pisa-2015-results-in-focus.pdf.

Kowiyah. 2012. Kemampuan Berpikir Kritis. Jurnal Pendidikan Dasar 3(5): 175- 179.

Kristianingsih, (2010). Peningkatan Hasil Belajar Siswa Melalui Model Pembelajaran Inkuiri dengan Metode Pictorial Riddle pada Pokok Bahasan Alat-alat Optik di SMP. Jurnal Pendidikan Fisika Indonesia, 6(3): 1013.

Lee, Che-Di. 2014. Worksheet Usage, Reading Achievement, Classes' Lack ofReadiness, and Science Achievement: A Cross-Country Comparison.International Journal of Education in Mathematics, Science and Technology,2(2), 96-106.

Masfer, A.A. 2014. Islamic Teachers' Perceptions of Improving Critical Thinking Skills in Saudi Arabian Elementary Schools. Saudi Arabia Canadian Center of Science and Education . 3(4): 37-48.

Masfuah, S. 2016 Pictorial Riddle Melalui Pembelajaran Attention, Relevance, Confidence, Satisfaction (ARCS) untuk Meningkatkan Kemampuan Pemecahan Masalah dan Motivasi Berprestasi Siswa. Jurnal Konseling Gusjigang, 2(1). 114-110.

Musharafa. 2016. Meningkatkan Kemampuan Berpikir Kritis Matematis Siswa melalui Pendekatan Metacognitive Instruction. Jurnal Pendidikan Matematika. 5(2): 28-35.

TIMSS. 2016. TIMSS 2015 International Results in Science: Findings From IEA's Trends In International Mathematics and Science study at the Fourth and Eighth Grades. United States. TIMSS \& PIRLS International Study Center. 